\title{
Spermatozoa observed a second time within the ovum
}

\author{
Martin Barry M.D. F.R.SS. L. and E.
}

To cite this article: Martin Barry M.D. F.R.SS. L. and E. (1843) Spermatozoa observed a second time within the ovum, Philosophical Magazine Series 3, 22:146, 415-415, DOI: 10.1080/14786444308636407

To link to this article: http://dx.doi.org/10.1080/14786444308636407

册 Published online: 01 Jun 2009.

Submit your article to this journal

Џ Article views: 3

Q View related articles $₫$ 
SPERMATOZOA OBSERVED A SECOND TIME WITHIN THE OVUM. By Martin BarRY, M.D., F.R.SS. L. and E.

Several months since, I compunicated to the Royal Society the fact that $I$ had observed, and shown to Professor Owen and others, spermatozoa within the mammiferous ovum. The ova were those of the rabbit, taken twenty-four hours post coittum from the Fallopian tube*.

I have this day confirmed the observation; several ova from the Fallopian tulse of another of these animals, in a somewhat earlier stage, having presented spermatozoa in their interior: i. e. (as in the first observation) within the thick transparent membrane (" zona pellucida") brought with the ovum from the ovary.

London, 31 III mo. (March) 1843.

Dr. Forster will publish at Bruges in a few weeks, a treatise on Comets, entitled “ Essai sur l'Influence des Comètes sur les Phénomenes de l'Atmosphère terrestre," \&c. To which is appended, "Essai sur les Étoiles flantes, avec une catalogue historique."

In March were published at Bruges, "Discours préliminaire a l'Étude de l'Histoire Naturelle,"par T. Forster, F.L.S., F.R.A.S., \&c. The object of this Treatise is to direct the student of Natural History in the true phrenological method of pursuing the same, and to point out the similarity of principleconspicuous through the organized animal kingdom.

METEOROLOGICAL OBSERVATIONS FOR MARCH 1843.

Chiswick.-March 1. Clear : some snow-flakes : frosty. 2, 3. Clear and frosty : fine. 4. Cloudy and fine : frosty at night. 5. Sharp frost : cloudy. 6. Cloudy : clear and frosty at night. 7. Frosty and foggy : cold with easterly haze. 8. Light clouds : fine : frosty. 9. Dry haze. 10. Hazy : overcast. 11. Slight haze. 12. Uniformly overcast. 13. Clear: cloudy and fine. 14. Fine. 15. Hazy : cloudy and fine. 16. Hazy and mild : clear and fine. 17, 18. Mornings foggy, clear and fine. 19. Foggy: fine. 20. Foggy : very fine: rain. 21, 22. Very fine. 23. Cloudy and mild. 24. Hazy : fine. 25. Dry and windy. 26. Cold and dry. 27, 28. Cloudy and cold. 29. Dry cold haze. 30, 31 . Overcast and fine.

Boston.-March 1. Fine : snow early A.M. : rain P.M. 2, 3. Fine. 4. Cloudy. 5. Fine. 6. Cloudy. 7. Fine. 8-10. Cloudy. 11. Fine. 12. Cloudy. 13. Fine. 14. Cloudy : rain early A.M. 15. Fine : rain early A.M. 16. Cloudy. 17, 18. Fine. 19. Cloudy. 20. Fine. 21. Fine : rain early A.M. 22. Rain: rain early A.M. 23, 24. Cloudy : rain early A.M. 25. Windy. 26. Stormy. 27, 28. Windy. 29, 30. Fine. 31. Cloudy.

Sandwick Manse, Orkney.-March 1. Snow-showers: frost. 2-5. Cloudy : thaw, 6. Clear : aurora. 7, 8. Clear: hoar-frost : aurora. 9. Clear : cloudy. 10. Cloudy : damp. 11. Damp. 12. Showers. 13. Snow : showers. 14. Snowing: clear. 15. Snow : showers : clear. 16. Cloudy : snow: rain. 17. Rain : drizzle. 18. Showers : clear: aurora. 19. Cloudy. 20. Cloudy : damp. 21, 22. Damp. 23. Damp : showers: damp. 24. Damp. 25-29. Bright: clear. 50. Cloudy : rain. 31. Drizzle: rain.

Applegarth Manse, Dumfries-shire-March 1-4. Frost : fair. 5. Slight frost : thaw P.M. 6. Thaw and drizzle. 7. Fair and fine: spring day. 8. Frost. 9. Frost : dull p.M. 10. Rain. 11. Very damp. 12. Wet A.M. : cleared up. 13. Fair and fine: drizzle. 14. Frost: threatening. 15. Frost: fine. 16. Drizzle. 17. Moist, but not rain. 18-20. Fair and fine. 21. Fair and fine: shower P.M. 22. Wet A.M. : cleared. 23, 24. Wet A.M. 25, 26. Fair, 2729. Fair : slight frost. 50. Heavy rain : thunder. 31. Ilain A.M.

* See Proceedings of the Royal Society, Dec. 8, 1842. 